정규논문 (Regular Paper)

방송공학회논문지 제18권 제2호, 2013년 3월 (JBE Vol. 18, No. 2, March 2013)

http://dx.doi.org/10.5909/JBE.2013.18.2.225

ISSN 2287-9137 (Online) ISSN 1226-7953 (Print)

$$
\begin{aligned}
& \text { 자극과 배경의 대비, 배경 텍스쳐 밀도, 자극의 화면 시차가 크로스톡 } \\
& \text { 지각에 미치는 영향 } \\
& \text { 박 종 진 }{ }^{a)} \text {, 이 형 철 }{ }^{\text {a }} \text {, 김 신 우 }{ }^{a)}
\end{aligned}
$$

\title{
The Effects of Stimulus-background Contrast, Background Texture Density and Screen Disparity of Stimulus on Crosstalk Perception
}

\author{
JongJin Park ${ }^{\mathrm{a})}$, Hyung-Chul O. $\mathrm{Li}^{\mathrm{a})^{\ddagger}}$, and ShinWoo Kim ${ }^{\mathrm{a})}$
}

요 약

$3 \mathrm{D}$ 영상을 시청하면서 느끼는 고유한 피로를 입체 시각 피로라고 부른다. 이 현상을 유발시키는 주된 요인으로 꼽히는 것은 화면 시차, 상 흐림, 크로스톡 (crosstalk)의 세 가지 요인으로 알려져 있다. 이 중 화면 시차와 상 흐림은 영상 콘텐츠에 의하여 결정되며, 사용하는 디스플레이 종류에 관계없이 직접 조작할 수 있다. 그러나 크로스톡 요인은 다른 요인과는 다르게 $3 \mathrm{D}$ 디스플레이의 물리적 인 특성에 의하여 결정되는 요인이며 따라서 손쉽게 감소시키거나 제거하는 것이 불가능하다. 그러나 크로스톡이 입체 시각 피로에 미 치는 영향은 자극 특성에 의하여 달라지며, 이러한 자극 특성은 조작 가능하다. 따라서 크로스톡이 입체 시각 피로에 미치는 영향을 확인하려면 크로스톡 지각에 영향을 미치는 자극 특성의 효과를 확인하여야 한다. 이런 목적을 달성하기 위하여 상대적 깊이 판단 과 제를 사용하여 자극 특성 (자극과 배경의 대비, 배경 텍스쳐 밀도, 자극의 화면 시차)이 크로스톡 지각에 미치는 영향을 확인하였다. 그 결과 영상에 배경이 존재하고 자극의 화면시차가 적을 때 지각되는 크로스톡이 감소함을 시사하는 결과를 얻었다.

\section{Abstract}

3D contents could cause unique 3D visual fatigue. Screen disparity, image blurring, and crosstalk are known to be the three major factors responsible for the fatigue. Among these, screen disparity and image blurring are content factors, that is, one can directly manipulate contents themselves to handle visual fatigue caused by these two factors. On the other hand, because crosstalk is closely tied to physical characteristics of 3D display, it is difficult or even impossible to reduce crosstalk-driven visual fatigue unless one replaces 3D display itself (for example, from active to passive display). However, the effects of crosstalk on 3D visual fatigue depends on visual stimulus features (that is, contents), and thus it is possible to manipulate stimulus features in order to handle visual fatigue caused by crosstalk. Hence, this research tested the effects of visual stimulus features on crosstalk (which then causes 3D visual fatigue). Using relative depth discrimination task, we tested the effects of stimulus-background contrast, background texture density, and screen disparity on the degree of perceived crosstalk. The results showed that crosstalk decreases with presence of background texture and with less degree of screen disparity.

Keyword : Perceived crosstalk, Background texture density, Screen disparity 


\section{I. 서 론}

우리의 시각 체계는 가까운 거리의 대상 (최대 약 5 미터 이내)을 바라볼 때 양 눈의 수평적 거리 차이에서 유발되는 상의 시차를 통하여 더 정확한 공간정보를 지각 한다 ${ }^{[1]}$. 이 런 양안 시차의 효과는 두 눈에 들어오는 상이 서로 상관을 가지면서 좌우로 약간 떨어진 위치에 맺힐 때 나타나며, $3 \mathrm{D}$ 디스플레이 영상이 2D 디스플레이에 비하여 더 실감나는 입체감을 가진 영상을 보여줄 수 있는 직접적인 깊이 단서 이다. 따라서 $3 \mathrm{D}$ 디스플레이에서 가장 기초적으로 구현되 어야 하는 기능은 양 눈에 서로 다른 영상을 제시하는 것이 다.

그러나 양안시차를 이용하여 실감나는 $3 \mathrm{D}$ 영상을 제시 하기 위하여 인간의 시각체계가 가지는 복잡한 기제에 완 전히 들어맞는 자극을 제시하는 것은 매우 어렵다. 양안 자 극 분리만 구현한 $3 \mathrm{D}$ 디스플레이는 거리와 관련된 다른 단 서, 예를 들면 수렴 눈 운동이나 조절 효과와 같은 단서의 불일치와 그에 따른 상 왜곡을 피할 수 없다 ${ }^{[2]}$. 이런 문제를 해결한 이상적인 $3 \mathrm{D}$ 디스플레이는 마치 거울처럼 작동할 것이다. 즉, 이 디스플레이를 통하여 제시된 영상은 마치 실제 대상을 바라보는 것처럼 깊이를 가지고, 시점에 따라 서 영상이 변화하며, 영상에 제시된 여러 대상 중 하나에 선택적으로 초점을 맞출 수 있을 것이다. 이런 3D 디스플레 이는 지속적으로 개발하고 있으나 아직 상용화 단계에 이 르지 못하였다 ${ }^{[3]}$.

따라서 현재 사용되는 3D 제시 방식은 단순히 하나의 디 스플레이에서 제시되는 영상을 양안에 각각 분리하여 제시 하는 방법을 사용한다. 영상을 분리하기 위하여 사용하는 방법은 안경을 통하여 3D 디스플레이를 바라볼 때 입체 경 험을 제공하는 안경식 $3 \mathrm{D}$ 디스플레이와 특별한 추가 도구

\footnotetext{
a) 광운대학교 (Kwangwoon University)

₹ Corresponding Author : 이형철(Hyung-Chul O. Li) E-mail: hyung@kw.ac.kr Tel: +82-2-940-5425

※본 연구는 지식경제부 및 한국산업기술평가관리원의 산업원천기술개발 사업[인체안전성을 위한 $3 \mathrm{D}$ 기기/장비 중심의 휴먼팩터 연구]과 광운대 학교 2012년도 교내연구비 사업(이형철)의 일환으로 수행하였음 - Manuscript received Deceber 27, 2012 Revised February 14, 2013 Accepted February 14, 2013
}

없이 입체 경험을 제공하는 무안경식 $3 \mathrm{D}$ 디스플레이로 나 뉜다. 안경식 $3 \mathrm{D}$ 디스플레이는 특수한 방식으로 영상을 제 공하는 $3 \mathrm{D}$ 디스플레이를 전용 안경을 통하여 바라볼 때 양 안에 분리된 자극을 제시하는 방식이다. 제시 방식에 따라 셔터 글래스 (Shutter Glass, SG) ${ }^{[4][5]}$ 방식과 편광 (Pattern Retarded, PR) 방식으로 ${ }^{[6]}$ 나뉘며 각각 시분할 및 공간분할 방식으로 디스플레이의 영상을 양안에 분할하여 제시한다. 무안경식 $3 \mathrm{D}$ 디스플레이는 빛을 최소한 두 방향에서 보내 디스플레이를 특정 시점에서 바라보면 양 눈에 서로 다른 영상이 제시되도록 하는 방법을 사용한다 ${ }^{[7]}$. 전면에 배리어 (barrier)를 설치하여 분할하는 방법을 패럴랙스 배리어 (Parallax barrier) 방식이라고 부르며, 렌즈 배열을 사용하 여 분할하는 방법을 렌티큘러 (Lenticular) 방식이라고 부른 다.

각 $3 \mathrm{D}$ 제시 방식은 서로 다른 장점과 단점을 가지기 때 문에 사용 환경에 따라 디스플레이에 쓰이는 3D 방식이 달 라지는 경향을 보인다. 안경 식 $3 \mathrm{D}$ 디스플레이는 안경을 착용해야 하는 불편함이 있으나 무안경식 $3 \mathrm{D}$ 디스플레이 의 관찰 시점이 고정된 것에 비하면 상당히 넓은 시점에서 자극을 볼 수 있다는 장점이 있다. 그래서 안경 식 $3 \mathrm{D}$ 제시 방식 (셔터글래스 (Shutter glass) 또는 편광 (Pattern retarded))은 최근 3D 영화의 흥행에 힘입어 가장 많이 보급 되고 있는 $3 \mathrm{D}$ 제시 방식이다. 이는 가정이나 영화관처럼 여러 각도에서 동시에 여러 사람이 $3 \mathrm{D}$ 영상을 시청해야 하 는 경우 가장 적절한 제시 방식이라고 할 수 있다. 반면에 주로 한 사람이 사용하고 관찰 시점이 고정됨을 가정하는 휴대용 기기의 경우, 안경 휴대의 불편함 없이 $3 \mathrm{D}$ 를 경험할 수 있는 패럴랙스 배리어를 사용한 무안경식 3D 제시 방식 을 사용한다. 이런 방식을 사용한 기기로는 LG Optimus $3 \mathrm{D}$ 나 닌텐도 $3 \mathrm{DS}$ 와 같은 기기가 있다.

그러나 이런 $3 \mathrm{D}$ 제시 방식은 양안의 영상을 분리하는데 목적을 두기 때문에 인간 시각체계가 필요로 하는 양안 정 보를 모두 제공하지 못하며, 따라서 다양한 종류의 영상 왜 곡이나 피로감이 나타나게 된다. 게다가 $3 \mathrm{D}$ 영상의 초점은 자극에 고정되어 있기 때문에 영상을 촬영한 사람이 초점 을 맞추지 않은 위치를 바라보게 되면 큰 시각피로를 느끼 게 되는 경우가 있다. 이러한 물리적 한계에 따른 지각 왜곡 
효과는 다른 물리적 특성에서도 나타날 수 있는데, 3D 시각 피로와 실감에 영향을 끼치는 가장 중요한 요인으로 꼽히 는 것 중 하나가 바로 크로스톡이다 ${ }^{[8][9][10]}$.

크로스톡은 사전적으로 통신의 혼선 또는 누화 등의 의 미를 가지지만, $3 \mathrm{D}$ 영상 분야에서는 좌안과 우안의 영상이 완전히 분리되지 않아 좌안의 영상 중 일부가 우안의 영상 에 섞이고, 우안의 영상 중 일부가 좌안에 섞이는 것을 의미 한다. 이런 현상은 $3 \mathrm{D}$ 디스플레이를 볼 때만 발생하며, 피 로감 및 불편감에 영향을 줄 뿐만 아니라 $3 \mathrm{D}$ 영상의 실감을 떨어뜨린다 ${ }^{[12][13]}$. 또한 주관적 $3 \mathrm{D}$ 피로 측정 연구 ${ }^{[1]}$ 에 따 르면, $3 \mathrm{D}$ 자극을 시청한 참가자가 일반적으로 보고하는 주 관적 피로감 및 불편감 증상은 크게 네 가지 요인 (시각적 스트레스, 안구 통증, 신체 통증, 상 흐림) 으로 나눌 수 있 으며 이 중 상 흐림 요인의 경우 특히 크로스톡과 화면 시차 에 의하여 직접적으로 유발될 수 있다.

크로스톡의 영상 실감 감소 효과 역시 인간의 시각 기제 와 밀접한 연관이 있다. 인간의 시각 체계는 두 눈에 들어온 영상이 이중상이면서 상관을 가질 때 대상이 되는 자극을 하나로 보기 위하여 수렴 눈 운동을 일으킨다. 이는 주시 대상에 화면 시차가 있는 경우 그 대상이 시차에 따라 깊이 를 가진 것으로 지각되도록 만드는 가장 기본적인 기제이 다 ${ }^{[14]}$. 그러나 크로스톡이 높으면 각 눈에 대측 자극이 섞여 들어가 양안에 동일한 자극을 제시되는 것과 같은 상황이 발생한다. 즉, 대상 자극이 양안시차를 가진 것이 아니라 원래 양안 자극이 겹쳐진 이중상을 가진 $2 \mathrm{D}$ 자극인 것처럼 지각하게 된다 ${ }^{[15]}$.

이와 같이 크로스톡은 $3 \mathrm{D}$ 영상의 깊이 지각을 방해하는 결정적인 요인 중 하나이다. 그리고 크로스톡은 물리적으 로 결정되어 있는 요인으로, 시청 환경 등에 따라서 차이가 나타날 수 있으나 객관적으로 측정이 가능하다. 그러나 물 리적 크로스톡이 동일한 경우에도 자극의 특성에 따라서 크로스톡이 다르게 지각되는 경향이 있다. 경험적으로 자 극의 시차가 크고, 주시 대상과 배경의 대비가 크며, 배경에 아무것도 없는 상태에서 주시 대상만 화면 시차를 가지는 경우에 크로스톡이 좀 더 현저하게 느껴지는 경향이 있다.

본 연구에서는 경험적으로 크로스톡에 영향을 줄 것으로 생각되는 자극 특성 (자극과 배경의 대비, 배경 텍스쳐 밀
도, 자극의 화면 시차)이 크로스톡 지각에 어떤 영향을 미치 는지 확인하였다. 지각된 크로스톡은 상대적 깊이 판단 과 제의 수행을 통하여 간접적으로 측정되었다. 크로스톡이 크게 지각되면 깊이 지각을 직접 방해받기 때문에 상대적 깊이 판단 과제의 수행 수준에 따라서 지각된 크로스톡 수 준을 간접적으로 확인할 수 있기 때문이다. 또한 이를 통하 여 어떤 자극 특성 변인을 조작하면 크로스톡의 효과를 감 소시킬 수 있는지 확인하였다.

\section{II. 실험}

\section{1. 연구 방법}

앞서 언급한 바와 같이 크로스톡은 측정 가능한 물리적 특성이다. 그러나 동일한 디스플레이를 사용하는 경우에도 자극의 특성에 따라 크로스톡이 지각되는 정도가 각각 다 르다는 것은 경험적으로 잘 알려진 사실이다. 크로스톡에 의하여 유발된 이중상은 양안 시차에 의한 입체 지각을 방 해하기 때문에 ${ }^{[5][13]}$ 디스플레이에서 크로스톡을 완전하게 제거할 수 없다면 관찰자가 어떤 조건에서 크로스톡을 더 크게 느끼는지 측정할 필요가 있다. 본 연구에서는 경험적 으로 지각된 크로스톡에 영향을 미칠 것으로 예측되는 변 인 (자극과 배경의 대비, 배경 텍스쳐 밀도, 자극의 화면 시 차) 이 크로스톡에 미치는 영향을 확인하고 그 방법을 바탕 으로 지각된 크로스톡을 측정하는 방법을 제안하고자 한다.

\section{2. 참가자 및 장치}

광운대학교 대학생 19 명이 유급으로 실험에 참가하였다. 모든 참가자는 정상 시력 또는 교정된 정상 시력을 가지고 있었고 양안 시차를 가진 자극에서 입체감을 문제없이 지각 할 수 있었다. 자극은 시판중인 46/47인치 3D TV를 사용하 여 제시되었다. 모든 디스플레이의 $3 \mathrm{D}$ 제시 방식은 안경을 사용하는 방식이었으며, $3 \mathrm{D}$ 제시 방식 (액티브, 패시브) 별 로 각각 한 대씩 사용하였다. 액티브 방식 디스플레이는 셔 터 글래스 (Shutter glass, SG) 방식 TV인 삼성 UN46C8000 
(46인치)을 사용하였고, 패시브 방식 장비는 편광 (Film pattern retarded, FPR) 방식 TV인 LG 47LW5700 (47인치) 을 사용하였다.

각 방식의 디스플레이는 서로 다른 방법으로 $3 \mathrm{D}$ 자극을 제시하기 때문에 서로 다른 특징을 가진다. 셔터 글래스 방 식 디스플레이는 시간을 분할하여 좌안과 우안의 영상을 나 눈다. $60 \mathrm{~Hz}$ 의 화면 갱신률로 입체 영상을 제시하려면 최소 한 2 배 이상 (즉 $120 \mathrm{~Hz}$ 이상)의 화면 갱신률을 가진 디스 플레이를 사용하여 좌안과 우안의 영상을 번갈아가면서 디 스플레이 화면에 표시한다. 3D 안경은 번갈아가며 깜빡이는 방법을 사용하여 디스플레이에 제시된 영상이 해당하는 눈 에 제시될 영상인 경우 영상을 투과하고, 반대편 눈에 제시 될 영상인 경우 차단한다. 이 방식은 디스플레이가 보여줄 수 있는 화면 해상력이 유지할 수 있다는 장점을 가진다. 그 러나 시분할 방식을 사용하기 때문에 영상의 깜빡임이 느껴 지는 경우가 있고, 화면이 어둡게 느껴지며 안경과 디스플레 이의 동기화가 반드시 필요하다. 또한 셔터 글래스가 완벽하 게 상을 차단하기 어렵기 때문에 PR 방식에 비하여 상대적 으로 높은 크로스톡을 가지는 경향이 있다.

편광 방식 디스플레이는 공간을 분할하여 좌안과 우안의 영상을 나눈다. 디스플레이의 홀수 열과 짝수 열에 각각 단 안 영상을 제시하며, 디스플레이 표면과 안경의 편광 필터 를 통하여 각 열의 영상을 선택적으로 좌안 및 우안으로 분리하여 제시한다. 이 방식은 다른 $3 \mathrm{D}$ 제시 방식에 비하여 깜빡임이나 크로스톡이 덜하다는 장점을 가지며, 안경은 단순히 편광 필터의 역할만 하기 때문에 가볍고 다양한 형 태로 제작할 수 있다는 장점이 있다. 그러나 영상이 공간적 으로 손실된다는 단점을 가진다. 즉 단안 영상은 디스플레 이가 표현할 수 있는 해상도의 절반만 사용할 수 있다. 그리 고 일반적으로 수직 시야각이 좁으며 시청 범위를 벗어나 면 깊이감이 역전되는 경우도 있다.

그러나 편광 방식이 상대적으로 매우 낮은 크로스톡을 가지지만 이 방식 역시 물리적으로 크로스톡을 완전히 제 거하는 것은 불가능하다. 즉 물리적인 크로스톡을 완전히 제거하는 것은 매우 어렵다. 그러나 경험적으로 콘텐츠 요 인의 변화에 따라서 지각된 크로스톡 수준은 달라지는 경 향을 보인다. 따라서 물리적인 크로스톡이 존재하더라도
콘텐츠 요인에 따라 크로스톡의 존재 여부가 잘 지각되지 않을 수 있다. 따라서 콘텐츠 요인에 따른 지각된 크로스톡 의 변화 정도를 확인하는 것은 중요한 문제가 될 수 있다.

연구에 사용된 디스플레이의 $3 \mathrm{D}$ 제시 방식이 서로 다르 기 때문에 물리적 크로스톡 역시 다르다. 본 연구에서는 실 험에 사용된 디스플레이의 물리적 크로스톡이 실험 참가자 에게 얼마나 전달되는지 확인하기 위하여 실험에 사용된 디스플레이를 실측한 값을 바탕으로 물리적 크로스톡을 계 산하였다. 측정 절차는 각 디스플레이에 자극과 배경의 대 비 조건에 따른 실험 자극 셋을 제시하고 $2 \mathrm{~m}$ 거리에서 휘 도계 (LS-110, Konica Minolta)를 사용하여 디스플레이에 제시된 자극, 배경, 그리고 고스트 이미지 (크로스톡에 의하 여 나타나는 대측 자극의 희미한 영상)가 나타나는 영역의 밝기를 측정하였다. 좌 / 우안 조건은 안경의 좌측 렌즈와 우측 렌즈를 측정 장치 앞에 대고 측정하는 방법을 사용하 여 구분하였다. 크로스톡은 고스트 이미지 밝기에서 배경 밝기를 차감하여 고스트 이미지 밝기만 구한 다음, 이 값과 자극 밝기의 비율로 계산하였다. 모든 대비 조건 (실험에 사용된 자극의 최대 대비, 중간 대비, 최소 대비 조건)의 자 극에서 측정한 크로스톡을 평균한 결과 편광 방식 디스플 레이의 크로스톡은 좌안 $0.81 \%$, 우안 $0.7 \%$ 였고 셔터 방식 디스플레이의 크로스톡은 좌안 $5.45 \%$, 우안 $8.85 \%$ 였다.

또한 자극을 실험에서 의도한 것에 정확하게 들어맞게 제시하기 위하여 MATLAB과 심리학 실험용 도구 모음인 Psychophysics toolbox를 사용하였다 ${ }^{[16]}$.

\section{3. 실험 설계 및 자극 구성}

본 연구의 목적은 지각된 크로스톡에 영향을 미칠 것으 로 예측되는 변인 (자극과 배경의 대비, 배경 텍스쳐 밀도, 자극의 화면 시차) 이 크로스톡에 미치는 영향을 확인하고 그 방법을 바탕으로 지각된 크로스톡을 측정하는 방법을 제안하는 것이다. 이런 목적을 달성하기 위하여 자극과 배 경의 대비, 배경 텍스쳐 밀도, 자극의 화면시차를 조작하여 다양한 특성을 가진 자극을 구성하였으며, 참가자가 이런 자극을 관찰하면서 상대적 깊이 판단 과제를 수행하도록 하여 깊이 판단 정확률이 자극 특성 및 $3 \mathrm{D}$ 제시 방식에 따 
라 어떻게 변화하는지 측정하였다.

상대적 깊이 판단 과제는 화면 시차를 가지는 자극을 제 시하고 그 자극의 위치가 화면보다 더 가까운지 아니면 더 먼지 판단하여 반응하는 과제이다. 이 과제를 사용하면 다 양한 변인이 크로스톡 지각에 미치는 영향을 간접적으로 확인할 수 있고, 크로스톡이 존재하는 경우에도 깊이 지각 을 상대적으로 안정되게 유지하는데 도움을 주는 자극 조 건을 확인할 수 있다. 왜냐하면 크로스톡이 더 크게 지각되 는 조건은 그렇지 않은 조건에 비하여 각 눈에 제시되는 자극에 대측 눈에 제시되어야 할 자극이 더 많이 섞여 들어 가 과제 수행, 특히 정확도가 떨어질 것이기 때문이다. 즉 양 눈에 제시된 자극이 동일한 것으로 지각될 가능성이 높 아진다. 따라서 수렴 눈 운동이 작게 유발되거나 또는 유발 되지 않을 것이며, 대상이 양안 시차를 가진 입체 자극이 아니라 좌안과 우안의 상이 겹쳐진 $2 \mathrm{D}$ 자극으로 지각하게 될 가능성이 높아진다. 즉 크로스톡이 증가함에 따라 입체 지각이 더 크게 방해받을 것이며 그 결과 참가자의 깊이 판단 정확률이 감소할 것이다.

그림 1 은 지각된 크로스톡에 영향을 줄 것으로 예측되는 자극 특성을 조작하였을 때 조건에 따라 자극에 어떻게 제

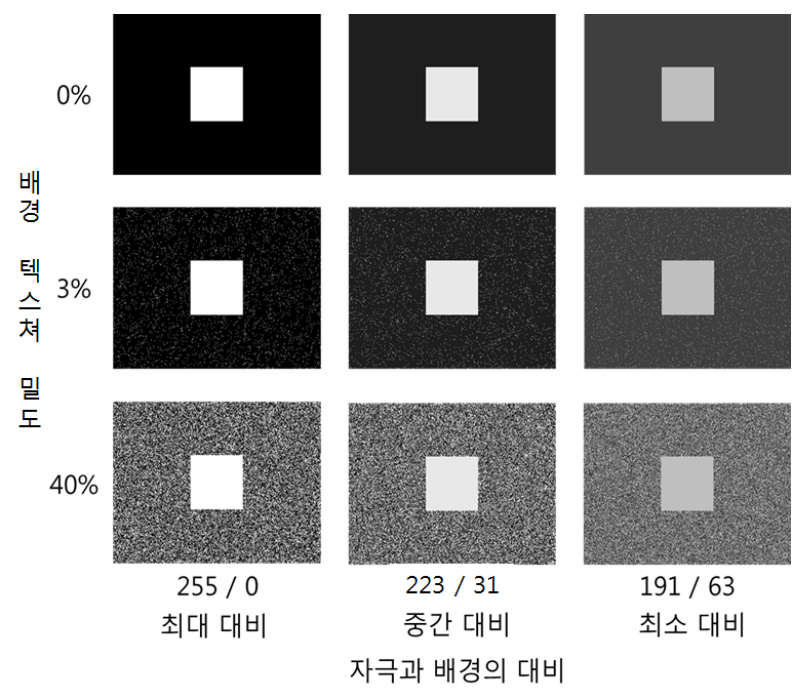

그림 1. 배경의 공간빈도 요인과 자극과 배경의 대비 요인 조건을 교차한 자극 예시

Fig. 1. Examples of test stimuli produced by combining background texture density and stimulus-background contrast
시되는지 보여준다. 화면 시차는 그림을 통하여 제시할 수 없기 때문에 자극과 배경의 대비 3 조건, 배경 텍스쳐 밀도 3 조건만 교차하여 구성하였다. 실험을 진행할 때는 화면 시차 6 조건 또한 교차하여 총 54 조건의 시행을 구성하였 고 각 조건을 6회씩 반복하였다. 모든 참가자가 두 디스플 레이에서 동일한 과제를 반복하여 수행하였다. 따라서 한 참가자는 한 TV에서 324회씩 총 648회의 과제를 수행하였 다.

실험 자극은 화면 시차를 가진 밝은 정사각형 (한 변의 길이 $20 \mathrm{~cm}$ ) 으로, 항상 자극이 배경보다 밝게 제시되었으 며, 그 자극 특성 변인 중 세 가지를 조작하였다. 첫째, 자극 과 배경의 대비 변인의 조건은 자극의 색과 배경의 색을 하나로 묶어 최대 대비 (자극 255 / 배경 0), 중간 대비 (자 극 223 / 배경 31), 최소 대비 (자극 191 / 배경 63) 세 조건 으로 정의하여 사용하였다 (그림 1 , 열에 따라 조건 제시). 각 대비 조건은 RGB코드로 정의된 밝기를 8 개로 분할하여 최대 대비 조건을 포함한 일부 조건을 사용하였다. 둘째, 배경 텍스쳐 밀도는 배경 공간에 제시된 자극과 동일한 색 을 가지는 점 밀도로 정의하였다 (그림 1 , 행에 따라 조건 제시). 배경 점의 위치는 항상 무선적으로 제시되었다. 자극 조건은 배경 점의 밀도 $0 \%$ (점 없음), $3 \%, 40 \%$ 로 총 3 조건을 사용하였다. 셋째, 자극의 화면 시차 조건은 안전 융합 영역 (양안시차 $\left.1^{\circ}\right)^{[17]}$ 을 기준으로 화면보다 가까운 조 건과 화면보다 먼 조건을 3 조건씩, 디옵터 (Diopter, $1 / \mathrm{m}$ ) 단위로 배치하여 구성하였다. 각 조건은 망막간 거리가 6.5 $\mathrm{cm}$ 일 때를 기준으로 안전 융합 영역 한계 시차 두 조건 $( \pm$ 0.3 디옵터), 작은 시차 두 조건 ( \pm 0.1 Diopter), 단일 상

표 1. 자극의 화면 시차 조건

Table 1. Screen disparities of stimuli

\begin{tabular}{|c|c|c|}
\hline $\begin{array}{c}\text { 화면에서 자ㄱㅡㅡㄲㄲ지의 거리 } \\
\text { (디옵터) }\end{array}$ & $\begin{array}{c}\text { 관찰자에서 자극까지의 } \\
\text { 거리 } \\
\text { (디옵터) }\end{array}$ & $\begin{array}{l}\text { 화ㅁㅕㅕ 시ㅊㅏㅏ } \\
\text { (시각도) }\end{array}$ \\
\hline-0.5 & 0 & $1^{\circ} 51^{\prime}$ \\
\hline-0.3 & 0.2 & $1^{\circ} 7^{\prime}$ \\
\hline-0.1 & 0.4 & 22' \\
\hline 0.1 & 0.6 & $22^{\prime}$ \\
\hline 0.3 & 0.8 & $1^{\circ} 7^{\prime}$ \\
\hline 0.6 & 1.1 & $2^{\circ} 14^{\prime}$ \\
\hline
\end{tabular}


형성 범위를 넘어서는 시차 두 조건 $(-0.5,+0.6$ 디옵터 $)$ 으 로 총 6 개 조건이었다. 표 1 에 각 조건의 값이 가지는 화면 시차 및 절대 거리 (자극으로부터 관찰자까지의 거리)를 디 옵터로 제시하였다. 화면시차가 없는 조건은 크로스톡의 측정과 무관하기 때문에 포함하지 않았다.

\section{4. 실험 절차}

앞서 언급한 바와 같이 물리적 크로스톡은 물리적 측정 을 통하여 확인할 수 있지만, 크로스톡 지각은 물리적 크로 스톡 뿐 아니라 다양한 자극 특성에 의하여 영향 받기 때문 에 정신물리학적 방법을 통하여 측정되어야 한다. 본 연구 에서는 서로 다른 크로스톡 수준을 가진 것으로 알려진 두 $3 \mathrm{D}$ 제시 방식 (SG와 FPR 방식)을 가진 디스플레이에서 상 대적 깊이 판단 과제를 사용하여 자극 특성이 지각된 크로 스톡에 미치는 영향을 확인하였다. 이 과제는 참가자에게 화면 중앙의 사각형이 화면보다 가까이 또는 멀리 제시된 것으로 보이는지 판단하고 그 결과를 키보드로 반응하는 것이었다.

전체 실험은 다음과 같은 순서로 진행되었다. 참가자는 실험에 대한 안내를 듣고 나서 TV로부터 시청 거리 $(2 \mathrm{~m})$ 만큼 떨어진 의자에 앉아서 정사각형의 상대적 깊이를 판 단하는 과제를 수행하도록 요청받았다. 깊이 판단 과제는 단순히 중앙의 사각형이 화면에 비하여 가까이, 또는 멀리 있는지 판단하여 키보드로 반응하는 과제였다. 자극은 1 초
간 제시되었으며, 5 초 이내에 응답하지 않은 조건은 실패로 간주하였다. 실험 조건은 54회의 수행을 한 단위로 하여 (자극과 배경의 대비 3 조건, 배경 텍스쳐 밀도 3 조건, 자극 의 화면 시차 6 조건을 모두 교차) 총 6 회 반복하였다. 어느 한 TV에서 수행을 끝마치면 다른 TV에서 동일한 과제를 수행하였다.

\section{5. 결과 및 논의}

디스플레이 제시 순서 (2 조건: 선 SG 후 FPR, 선 FRP 후 $\mathrm{SG}), 3 \mathrm{D}$ 제시 방식 (2 조건: $\mathrm{SG}, \mathrm{FPR})$, 자극과 배경의 대비 (3조건: 최대 255/0, 중간 223/3, 최소 191/63), 배경 텍스쳐 밀도 (3 조건: $0 \%, 3 \%, 40 \%)$, 자극의 화면 시차 (6 조건: $-0.5,-0.3,-0.1,0.1,0.3,0.6)$ 가 참가자들의 깊이 판단 정확률에 미치는 영향을 확인하기 위하여 혼합 설계 변량 분석을 사용하여 측정 결과를 분석하였다. 그 결과 세 가지 요인 (디스플레이 종류, 배경 텍스쳐 밀도, 자극의 화면 시 차) 에서 주 효과가 유의미하게 나타났다.

디스플레이 종류의 주 효과는 통계적으로 유의미하였으 며 $(\mathrm{F}(1,17)=7.7, \mathrm{p}<.01$, 그림 2 좌측 $), \mathrm{FPR}$ 방식의 깊이 판단 정확률이 $3.6 \%$ 높았다. 또한 이 조건에 따른 수행 차 이는 모든 조건에서 일관적으로 나타났다. 이 결과는 이 과 제의 수행이 FPR 방식과 SG 방식 사이의 물리적 크로스톡 차이를 반영함을 시사한다.

배경 텍스쳐 밀도의 주 효과도 통계적으로 유의미하였다
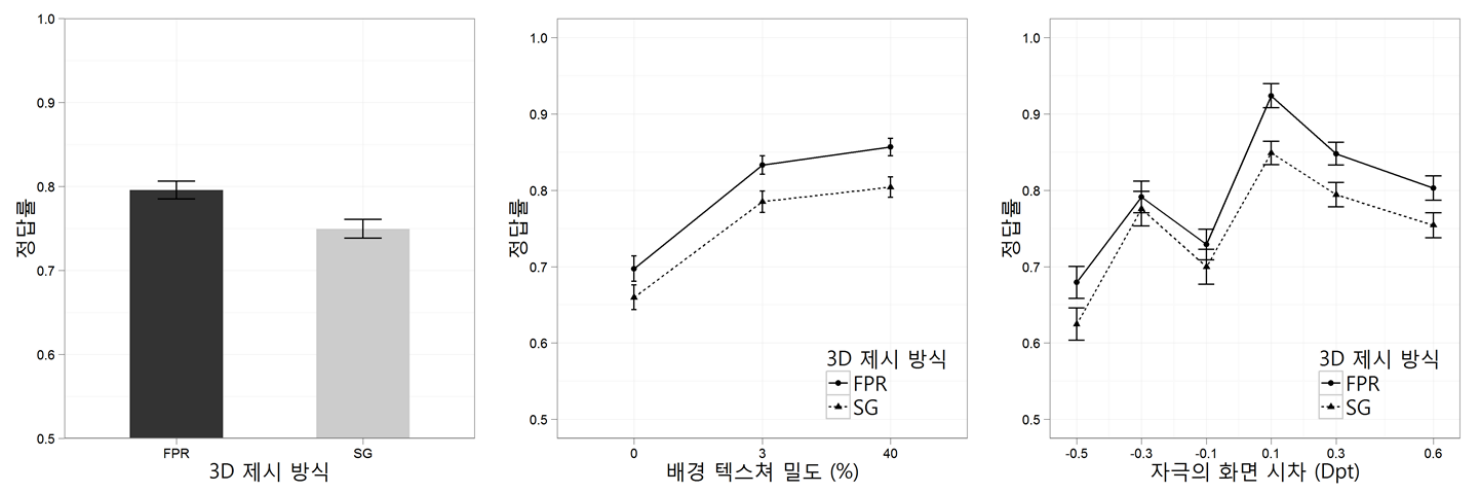

그림 2. 3D 제시 방식, 배경 텍스쳐 밀도, 화면시차에 따른 정답율

Fig. 2. Mean accuracy as a function of $3 \mathrm{D}$ display type, background texture density, and screen disparity 
$(\mathrm{F}(2,34)=6.5, \mathrm{p}<.001$, 그림 2 중앙 $)$. 즉 배경이 없을 때 보다 낮은 밀도라도 배경에 텍스쳐가 제시된 경우 깊이 판단 정확률이 증가하였다. 이는 배경 텍스쳐 밀도가 존재 하는 조건은 무선 점으로 이루어진 배경이 화면에 위치하 게 되어 깊이 판단의 기준이 될 수 있기 때문인 것으로 추정 된다. 이는 각 조건 간 차이를 Bonferroni의 방법으로 교정 하여 비교한 결과에서도 나타났다. 즉, $0 \%$ 대 $3 \%, 0 \%$ 대 $40 \%$ 조건의 경우 조건 간 차이가 통계적으로 유의미하였 으나 (FPR 방식: $0 \%$ vs. $3 \%, \mathrm{p}<.001,0 \%$ vs. $40 \%, \mathrm{p}<$ $.001, \mathrm{SG}$ 방식: $0 \%$ vs. $3 \%, \mathrm{p}<.005,0 \%$ vs. $40 \%, \mathrm{p}<$ $.005) 3 \%$ 대 $40 \%$ 조건의 경우 통계적으로 유의미한 차이 가 발견되지 않았다 (FPR 방식: $3 \%$ vs. $40 \%, \mathrm{p}=.23, \mathrm{SG}$ 방식: $3 \%$ vs. $40 \%, \mathrm{p}=.16$ ).

자극의 화면 시차 조건 역시 화면 시차에 따른 깊이 판단 정확률의 차이가 통계적으로 유의미하게 나타났다 $(\mathrm{F}(5$, $85)=22.6, \mathrm{p}<.001$, 그림 2 우측). 이 요인은 - 0.1 Diopter 조건에서 수행이 떨어진 것을 제외하면 전반적으로 대비가 클수록 과제 정답률이 낮아지는 경향을 보인다. 이 조건은 경험적으로 화면 시차의 크기에 비하여 입체감이 잘 지각 되지 않는 조건으로, 과제 정답률이 낮아지는 것은 반복적 으로 나타나는 현상이다. 자극의 화면 시차에 따라 깊이 판 단 정확률이 떨어지는 원인은 크로스톡의 영향보다 자극 조건의 수렴 요구가 점차적으로 더 커지기 때문이며, 이는 예측 가능한 결과이다. 매 시행에서 자극이 제시되기 전에 수렴 거리 및 초점 거리가 관찰자에서 화면까지의 거리가 된다. 자극은 갑자기 중앙에 특정 화면시차를 가지고 제시 되기 때문에 교차 화면시차를 가지는 자극 (상대적 깊이 조 건이 양수인 자극)은 갑자기 관찰자에게 접근하는 자극이 되고, 비교차 화면 시차를 가지는 자극 (상대적 깊이 조건이 음수인 자극)은 갑자기 관찰자로부터 멀어지는 자극이라고 볼 수 있다. 또한 이런 수렴 요구 측면에서, 비교차 시차 조건에서 낮은 수행을 보이는 것은 인간의 시각 체계가 일 반적으로 멀어지는 자극보다 다가오는 자극에 대하여 더 크게 반응한다는 것을 ${ }^{[18]}$ 반영한 효과라고 할 수 있다. 이는 화면보다 멀리 떨어진 조건의 정답률이 화면보다 가까운 조건에 비하여 전반적으로 더 낮으며, 안정적으로 융합할 수 있는 한계 영역 내에서 가장 큰 화면시차를 가진 -0.3

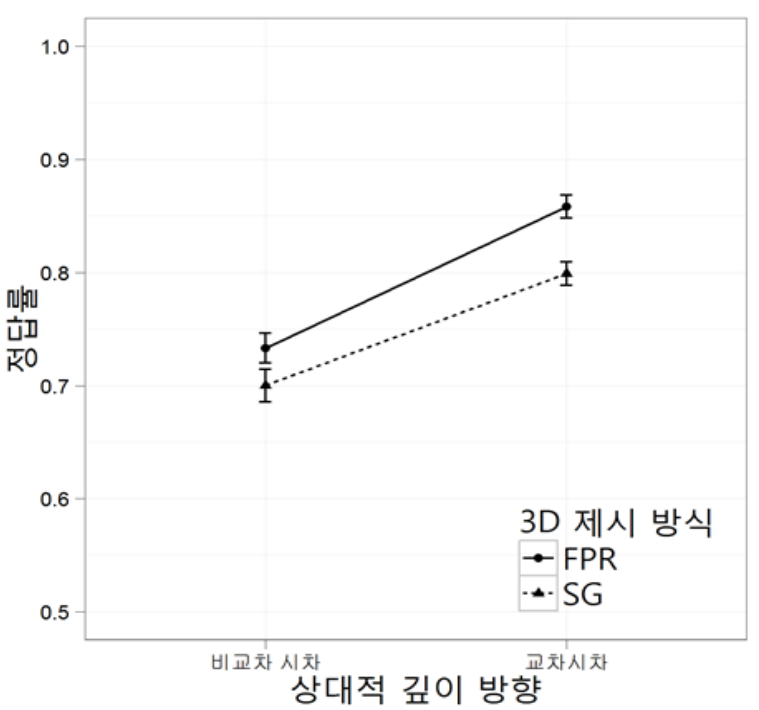

그림 3. 3D 제시 방식과 상대적 깊이에 따른 정답률

Fig. 3. Mean accuracy as a function of $3 \mathrm{D}$ display type and relative depth

조건을 제외하면 화면보다 가까운 조건에 비하여 매우 낮 은 정답률을 보이는 것으로 확인할 수 있다. 이런 차이를 통계적으로 확인하기 위하여 상대적 시차와 $3 \mathrm{D}$ 제시 방식 간의 차이를 Bonferroni의 방법으로 조건 간 짝 비교한 결 과 (그림 3), 자극이 교차 시차를 가질 때는 조건 간 차이가 통계적으로 유의미하였으나 비교차 시차를 가질 때는 차이 가 통계적으로 유의미하지 않았다 (교차-SG 방식 vs. 교차 -FPR 방식, $\mathrm{p}<.005$, 비교차-SG 방식 vs. 교차-FPR 방식, $\mathrm{p}=.63)$.

한편 디스플레이 제시 순서 $(\mathrm{F}(1,17)=.07, \mathrm{p}=.80$, 그림 4 좌측) 및 자극과 배경의 대비 조건 $(\mathrm{F}(2,34)=2.06, \mathrm{p}$ $=.14$, 그림 4 우측)의 차이는 통계적으로 유의미하지 않았 다 (그림 3). 디스플레이 제시 순서의 주 효과는 나타나지 않았으나 (그림 4, 좌측) 다른 변인과의 상호작용 효과가 나타났다 (그림 5,6). 자극과 배경의 대비 조건 요인의 경 우 주효과가 통계적으로 유의미하게 나타나지 않았는데, 이는 대비가 높은 조건 사이에서는 대비의 차이가 크로스 톡 지각에 미치는 영향이 제한적임을 시사한다 (그림 4, 우 측). 그러나 본 연구 결과만으로 대비가 크로스톡 지각에 미치는 영향을 전부 검증했다고 말하기 어렵다. 본 연구의 

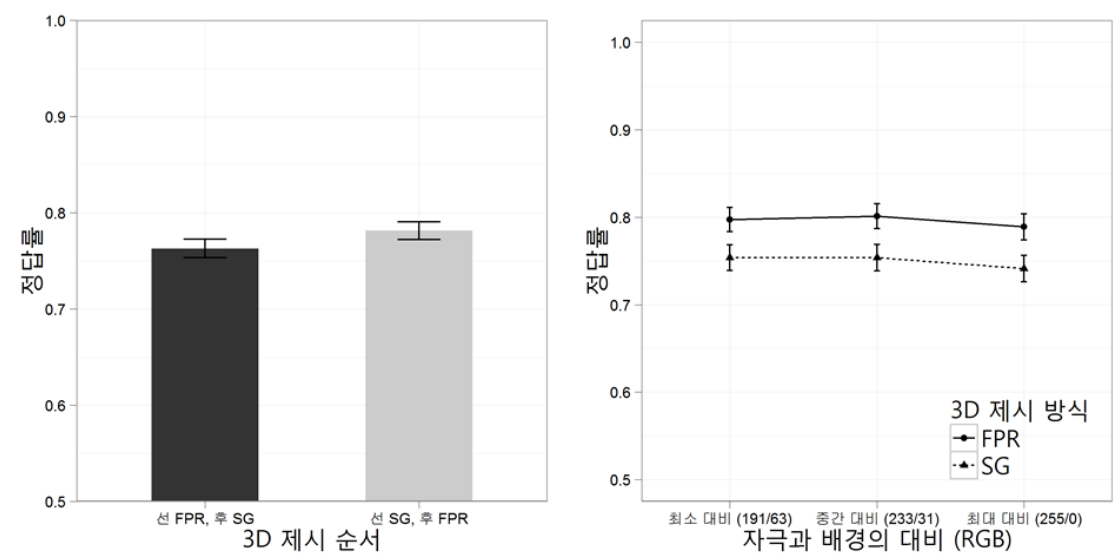

그림 4. 3D 제시 순서와 자극-배경 대비에 따른 정답율

Fig. 4. Mean accuracy as a function of the order of $3 \mathrm{D}$ display type and stimulus-background contrast

자극과 배경의 대비 조건의 경우, 자극에 사용된 대비 조건 이 상대적으로 대비가 큰 조건에 편중되어 있기 때문이다. 따라서 대비가 크로스톡 지각에 미치는 영향을 정확히 파악하려면 좀 더 넓은 범위의 대비 조건을 사용한 추가 연구가 필요할 것으로 보인다.

\section{1 고차 상호작용에 대한 추가 분석}

분석 결과 $3 \mathrm{D}$ 제시 순서를 포함한 두 개의 유의미한 상 호작용 효과가 나타났다. 본래 세 요인 이상의 상호작용 효과는 그 의미를 해석하는 것이 까다롭고 효과가 가리키
는 바가 명확하지 않다. 게다가 여기서 분석된 효과는 연구 의 주된 관심사가 아니기 때문에 디스플레이 제시 순서가 가지는 효과에 관심을 가지고 있는 독자만 읽기 바란다.

상호 작용 효과가 나타난 요인들은 배경 텍스쳐 밀도, $3 \mathrm{D}$ 제시 방식, 디스플레이 제시 순서 조건의 3원 상호작용 (그 림 5)과 자극과 배경의 대비, 자극과 화면의 시차, $3 \mathrm{D}$ 제시 방식, 디스플레이 제시 순서 조건의 4 원 상호작용 효과였다 (그림 6).

배경 텍스쳐 밀도, 3D 제시 방식, 디스플레이 제시 순서 조건의 상호작용 효과 $(\mathrm{F}(2,34)=5.29, \mathrm{p}<.01)$ 의 결과는

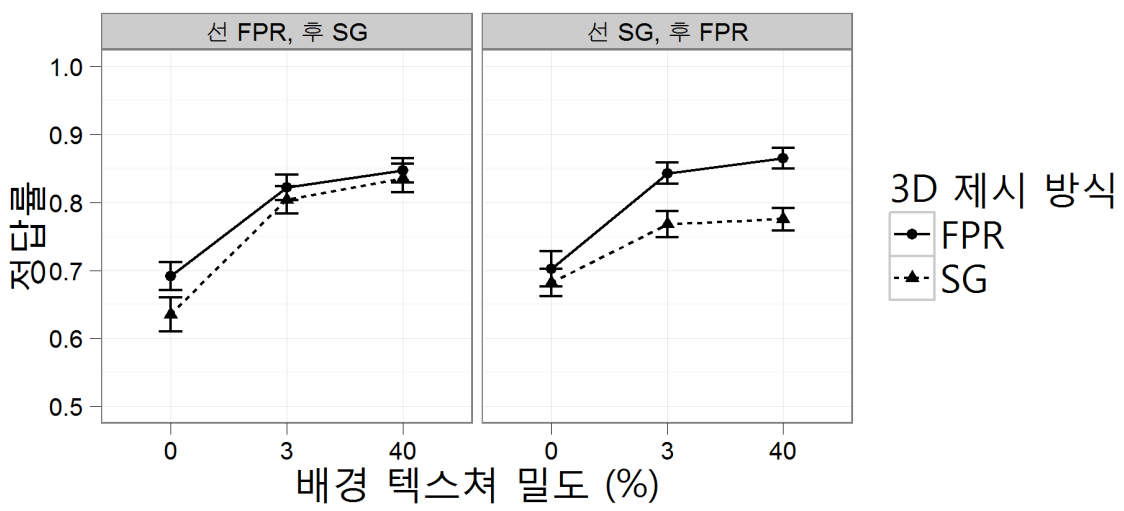

그림 5. 배경 텍스쳐 밀도, 3D 제시 방식, 디스플레이 제시 순서의 상호작용

Fig. 5. Interaction between background texture density, $3 \mathrm{D}$ display type, and the order of $3 \mathrm{D}$ display type 


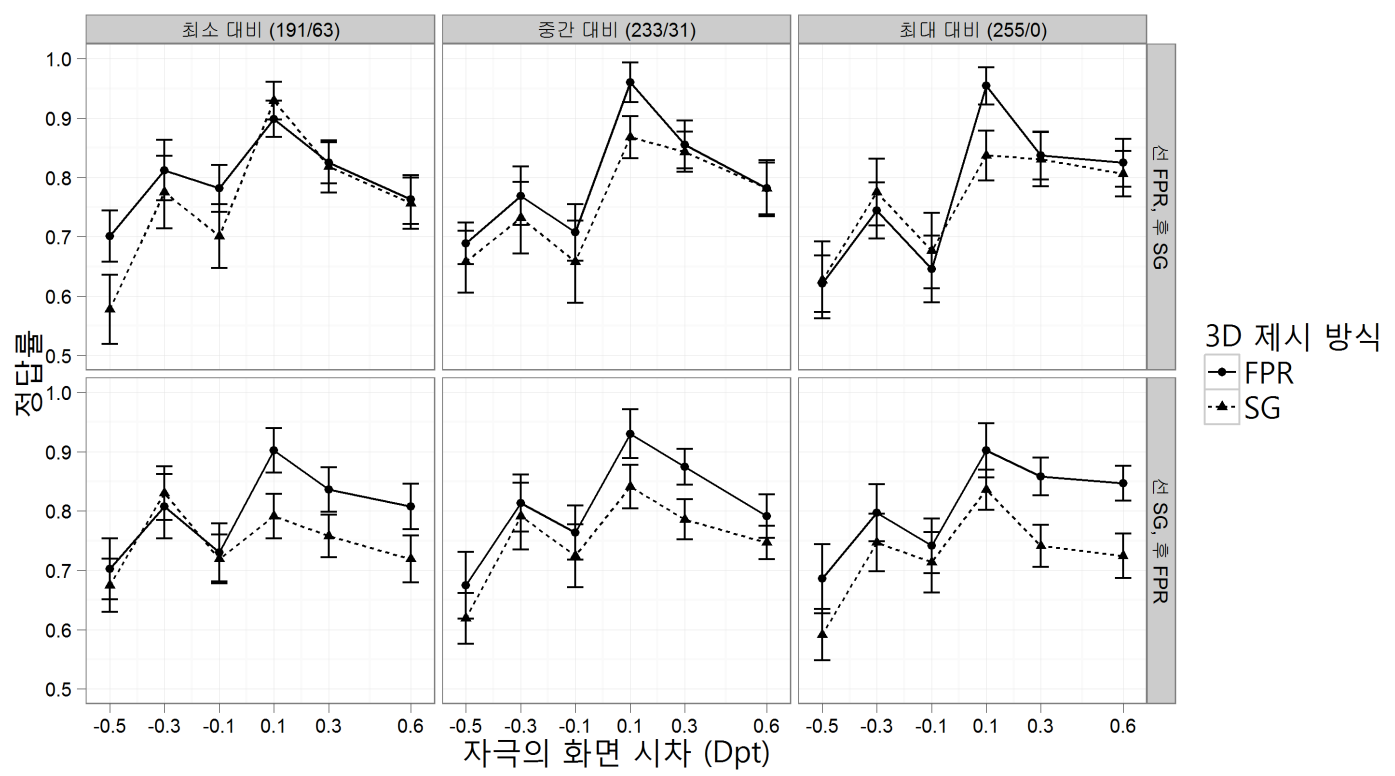

그림 6. 자극-배경의 대비, 화면시차, 3D 제시방식, 디스플레이 제시 순서 조건의 상호작용

Fig. 6. Interaction between stimulus-background contrast, screen disparity, 3D display type, and the order of 3D display type

FPR 방식 디스플레이에서 자극을 먼저 제시하는 것이 더 높은 깊이 판단 정답률을 보인 것으로 나타났다 (그림 5). 이는 FPR 방식에서 배경 텍스쳐 밀도 정보를 깊이 판단 과 제에 이용하는 방법을 쉽게 학습 할 수 있기 때문일 가능성 이 있다. 즉 FPR 방식 디스플레이에서 먼저 측정한 집단은 배경 텍스쳐 밀도가 주어지는 조건에서 배경 텍스쳐 밀도 가 깊이 판단 과제에 주는 영향을 쉽게 학습하고 그 결과를 $\mathrm{SG}$ 방식 디스플레이 과제에서 적용할 수 있으나, SG 방식 은 높은 크로스톡 때문에 배경 텍스쳐 밀도가 자극의 깊이 판단 과제에 주는 영향을 파악하기 어려운 것일 가능성이 있다.

자극과 배경의 대비, 자극과 화면의 시차, 3D 제시 방식, 디스플레이 제시 순서 조건의 상호작용 효과 $(\mathrm{F}(10,170)$ $=2.03, \mathrm{p}<.05$, 그림 6$)$ 역시 SG 방식 디스플레이를 먼저 관찰했을 때 FPR 디스플레이 조건에서 대비 조건에 따른 깊이 판단 정확률이 더 높게 나타난다. 이 조건 역시 $\mathrm{SG}$ 방식 디스플레이를 먼저 본 조건에서 FPR 방식의 디스플레 이 조건의 깊이 판단 정확률이 높다.

두 상호작용 결과를 종합하면 크로스톡이 높은 디스플레 이에서 먼저 과제를 수행할 때 크로스톡이 낮은 디스플레
이에서 먼저 과제를 수행할 때 보다 두 디스플레이 사이의 깊이 판단 정확률의 차이를 감소시키는 경향을 보인다. 따 라서 이 결과를 받아들인다면 연속적으로 서로 다른 수준 의 크로스톡을 가진 디스플레이를 평가할 때 미리 학습 시 행을 충분히 가지거나 각 측정 사이에 휴식 시간을 두는 등 순서 효과를 배제하기 위한 노력이 필요할 것이다.

\section{III. 결론 및 종합 논의}

본 연구의 목적은 여러 자극 특성이 변할 때 물리적 크로 스톡이 실제로 관찰자가 지각하는 크로스톡에 어떤 영향을 미치는지 확인하는 것이었다. 이 결과를 통하여 자극 특성 이 크로스톡에 미치는 영향을 두 가지 측면에서 확인하고 자 하였다. 첫째, 물리적 크로스톡이 큰 경우에도 안정적으 로 입체감 지각을 돕는 자극 특성을 밝히고자 하였다. 둘째, 지각된 크로스톡을 측정하기 위한 적절한 방법을 제안하고 자 하였다.

첫 번째 목적은 물리적 크로스톡이 큰 경우에도 안정적 으로 입체감을 지각하는데 도움을 주는 자극 특성이 무엇 
인지 확인하는 방법으로 달성할 수 있다. 측정 결과 배경 텍스쳐가 존재하고 (즉 배경 텍스쳐 밀도가 $0 \%$ 가 아니고) 자극의 화면시차가 낮을 때 상대적 깊이 판단 과제의 수행 이 증가하는 것을 확인할 수 있었다. 특히 배경 텍스쳐 밀도 는 그 효과가 크고 명확하게 나타났다. 그러나 분석 결과가 시사하는 바는 실제 크로스톡 감소에 영향을 미친 것은 배 경 텍스쳐의 밀도 차이보다 배경 텍스쳐 존재 유무라고 볼 수 있다. 그림 2에서 볼 수 있듯이, 배경 텍스쳐 밀도가 $0 \%$ 인 조건과 $3 \%$ 사이의 깊이 판단 정확률 차이는 통계적으로 유의미하였으며 효과 차이도 SG 방식과 FPR 방식 사이의 차이인 $4.6 \%$ 에 비하여 2 배 이상 크게 나타났으나 (FPR: $13.6 \%, \mathrm{SG}: 12.5 \%) 3 \%$ 조건과 $40 \%$ 조건 사이의 차이는 통계적으로 유의미하지 않았다. 이는 배경에 작은 차이라 도 텍스쳐 밀도를 높일 수 있는 대상을 배치하면 크로스톡 의 영향을 감소시키는데 큰 도움을 주지만 텍스쳐의 밀도 가 더 커진다고 해도 효과가 증가하지 않음을 시사한다. 특 히 $3 \%$ 조건의 경우에도 그 차이가 $3 \mathrm{D}$ 제시 방식 사이의 차이보다 2 배 이상 크기 때문에 화면 시차에 의한 깊이 지 각이 중요한 자극의 경우 자극 자체 뿐 아니라 배경 텍스쳐 밀도 역시 고려하여 자극을 구성할 필요가 있음을 보여준 다.

화면 시차는 상대적 깊이에 따라 깊이 판단 정확률에 서 로 다른 영향을 미쳤다. 자극의 화면 시차가 비교차인 경우 $\mathrm{SG}$ 와 FPR 방식 사이의 평균 차이는 통계적으로 유의미하 지 않았으나, 자극의 화면 시차가 교차 시차인 경우에는 SG 와 FPR 방식 사이의 평균이 통계적으로 유의미한 차이를 보였다 (그림 3). 보편적으로 3D 영상물을 보면서 기대하는 실감 효과는 자극이 “튀어나와” 보이는 것이다. 따라서 상 대적으로 물리적 크로스톡이 낮은 디스플레이는 그렇지 않 은 디스플레이에 비하여 $3 \mathrm{D}$ 제시에 근본적인 장점을 가진 다. 이는 그림 3에서 나타난 SG 와 FPR 방식 사이의 깊이 판단 정확률 차이에서 확인할 수 있다. 즉, 화면 시차가 동 일한 자극이라도 물리적 크로스톡이 낮은 디스플레이를 통 하여 제시하는 경우 입체 지각이 더 안정적으로 이루어진 다.

두 번째 목적은 $3 \mathrm{D}$ 디스플레이의 크로스톡을 지각적으 로 측정하기 위한 작업에 본 연구의 결과가 두 가지의 시사
점을 줄 수 있음을 밝히는 것으로 달성할 수 있다. 첫째, 지각된 크로스톡은 물리적 크로스톡과 큰 차이를 보이지 않았다. 즉 $3 \mathrm{D}$ 제시 방식을 제외하면 다른 자극 특성 (자극 과 배경의 대비, 배경 텍스쳐 밀도, 자극의 화면시차) 사이 의 상호작용은 나타나지 않았다. 이는 자극 특성이 그 자체 로 지각된 크로스톡에 체계적인 영향을 미치지 않음을 의 미한다. 따라서 물리적 크로스톡은 지각된 크로스톡을 예 측하기 위한 적절한 변인이라고 할 수 있다. 둘째, 크로스톡 을 완전히 제거할 수 없다면, 입체 자극을 구성할 때 지각된 크로스톡의 효과에 영향을 미치는 변인 (배경 텍스쳐 밀도, 자극의 화면 시차)을 반드시 고려하여야 한다는 점이다. 특 히 자극을 제시할 때 사용하는 $3 \mathrm{D}$ 디스플레이의 물리적 크 로스톡이 높으면 배경 텍스쳐 밀도를 추가하고, 자극의 화 면 시차 수준을 안전 융합 영역 이내 (양안시차 $1^{\circ}$ )로 제한 하면 크로스톡이 깊이 지각에 미치는 영향을 최소화시킬 수 있을 것이다.

이런 시사점은 다양한 분야에서 직접 응용될 수 있다. 현 재 $3 \mathrm{D}$ 영상이 다시 큰 관심을 얻게 된 이유는 엔터테인먼트 영역에서 시작된 $3 \mathrm{D}$ 붐이었다. 영화나 게임 같은 영상물이 $3 \mathrm{D}$ 로 제시될 때 사람들이 기대하는 것은 더 높은 실감이나 입체감이며, 시청자들이 반드시 정확한 공간적 관계를 지 각해야 할 필요는 없다. 반면에 다른 응용 분야에서는 이러 한 정확하고 직관적인 입체 지각정보가 필요하다. 의료 분 야의 영상 시각화나 학습 목적의 그림의 경우 단순한 $2 \mathrm{D}$ 영상으로 그 공간적 관계를 정확하게 묘사할 수 없는 경우 가 많다. 또한 이런 상황에서 사용하는 영상은 측정 결과나 본래 대상을 바탕으로 컴퓨터로 생성된 것으로, 쉽게 다양 한 효과를 부여할 수 있다. 따라서 생성된 영상에 깊이 수준 을 적절히 재구성하고 낮은 밀도의 텍스쳐로 구성되더라도 배경을 넣는 등 다양한 처리를 추가하면 영상이 정확하게 지각되는데 큰 도움을 줄 수 있다.

한편 본 연구에서 그 목적을 완전하게 달성하기에 부족 한 부분 역시 존재한다. 첫째, 몇몇 변인의 경우 전체 영역 에 대한 측정이 이루어지지 않아 그 효과가 명확하지 않았 다. 특히 자극과 배경의 대비 요인의 경우, 상대적으로 높은 대비 영역에서만 측정이 이루어져 대비가 지각된 크로스톡 에 미치는 영향을 전체적으로 확인할 수 없었다. 둘째, 크로 
스톡이 디스플레이 사이에서 측정되어 그 수준이 명확하지 않았다. 좀 더 정확하게 크로스톡의 영향을 확인하려면 크 로스톡이 없는 디스플레이에서 크로스톡을 시뮬레이션하 고 크로스톡에 따른 차이를 확인하는 것이 필요하다. 그러 나 본 연구에서는 물리적 크로스톡이 서로 다른 두 디스플 레이를 사용하였으며, 잠재적으로 나타날 수 있는 크로스 톡 변화에 따른 변인의 효과를 확인하는 것이 제한되었다. 또한 본 연구 결과를 확장하여 다른 상황에 적용시키는 것 역시 필요하다. 왜냐하면 본 연구의 결과는 주로 안경 식 디스플레이를 사용하는 경우에만 적용시킬 수 있기 때 문이다. 현재까지 연구된 무안경식 $3 \mathrm{D}$ 제시 방식은 $\mathrm{FPR}$ 방식과 유사한 일종의 공간적 분할 방식이며, 특정 시점에 서 바라보는 경우 양안의 영상이 분리되어 제시된다. 이런 방식의 디스플레이는 바라보는 방향에 따라 크로스톡이 실 시간으로 변하거나 ${ }^{[19]}$ 입체감이 사라질 수 있다리 ${ }^{[20]}$ 따라서 이런 무안경식 $3 \mathrm{D}$ 제시 방식에서 나타날 수 있는 크로스톡 문제는 본 연구에서 연구한 디스플레이에서 발생할 수 있 는 문제와 질적으로 다른 형태로 나타날 가능성이 존재한 다. 따라서 무안경식 $3 \mathrm{D}$ 디스플레이의 크로스톡 문제를 해 결하기 위해서는 본 연구 결과를 확장하여 무안경식 디스 플레이의 특성에 맞는 추가적인 연구를 수행해야 할 필요 성이 있다.

\section{참 고 문 헌}

[1] Gillam, B. The perception of spatial layout from static optical information, in Perception of space and motion. edited by Epstein, W. and Rogers, S. Academic Press, California. 27, 1995.

[2] Howarth, P. A. Potential hazards of viewing 3 D stereoscopic television, cinema and computer games: a review. Ophthalmic and Physiological Optics, 31(2), pp.111-122. 2011.

[3] Takaki, Y. and Nago, N., Multi-projection of lenticular displays to construct a 256-view super multi-view display. Optics Express, 18(9), pp.8824-8835. 2010.

[4] Milgram. P. and Van der Horst. R. Alternating-field stereoscopic dis- plays using light-scattering liquid crystal spectacles. Displays, 7, pp.67-72. 1986.

[5] Harris M.R., Geddes. A.J., and North. A. C. T. Frame-sequential stereoscopic system for use in television and computer graphics. Displays, 7, pp.12-16. 1986.

[6] Lane. B. Stereoscopic displays. Processing and display of three-dimensional data; Proceedings of the SPIE Meeting, San Diego, CA, USA. pp.20-32. 1983.

[7] Dodgson, N. A. Autostereo displays: 3D without glasses. EID: Electronic Information Displays, 1997.

[8] Kooi, F. L. and Toet, A. Visual comfort of binocular and 3-D displays. Displays, 25, pp.99-108, 2004.

[9] IJsselsteijn. W. A., Seuntiens. P. H. J., and Meesters. L. M. J., 3D Videocommunication-Algorithms, Concepts and Real-Time Systems in Human-centred Communication, New York. pp.219-234, 2005.

[10] Woods A., Docherty. T., and Koch. R., Image Distortions in Stereoscopic Video Systems, Proc. SPIE 1915, pp.36 - 49. 1993.

[11] Hyung-Chul O. Li, Human Factor Research on the Measurement of Subjective Three Dimensional Fatigue, Journal of Broadcast Engineering of Korea, 15(5), pp.607-616, 2010.

[12] Wang, L., Tu, Y., Chen, L., Zhang, P., Teunissen, K.m and Heynderickx, I. Crosstalk acceptability in natural still images for different (auto) stereoscopic display technologies, Journal of the SID, 18(6), pp.405-414, 2010.

[13] Woodgate. G. and Harrold. J. High efficiency reconfigurable 2D/3D autostereoscopic display,” SID Symp. Digest Tech. Papers, 34(1). pp.394-397, 2003.

[14] Rashbass. C. and Westheimer. G. Disjunctive eye movements. J Physiol. 159, pp.339-360. 1961.

[15] M. Siegel, Perceptions of crosstalk and the possibility of a zoneless autostereoscopic display. Proc. SPIE, 4297, 34 - 41. 2001.

[16] Diopter Kleiner, M., Brainard, D. and Pelli, D., What's new in Psychtoolbox-3? Perception 36 ECVP Abstract Supplement. 2007

[17] Fry, G. Further experiments on the accommodative convergence relationship. American Journal of Optometry, 16, pp.325 - 334. 1939.

[18] Busettini, C., Miles, F. A., and Krauzlis, R. J. Short-latency disparity vergence responses and their dependence on a prior saccadic eye movement. Journal of Neurophysiology, 75(4), pp.1392-1410. 1996.

[19] Duk-Joong Kim, Hyung-Chul O. Li, and ShinWoo Kim, Glasses-free Interactive 3D Display: The Effects of Viewing Distance, Orientation and Manual Interaction on Visual Fatigue, Journal of Broadcast Engineering of Korea, 17(4), pp.572-582, 2012.

[20] Giseok Kim, Jae-Soo Cho, and Gi-Mun Um, Robust Viewpoint Estimation Algorithm for Moving Parallax Barrier Mobile 3D Display, Journal of Broadcast Engineering of Korea, 17(5), pp.817-826, 2012. 


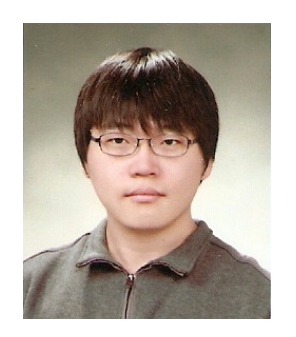

\section{박 종 진}

- 2009년 : 광운대학교 산업심리학과 학사

- 2011년 : 광운대학교 산업심리학과 석사

- 2011년 현재 : 광운대학교 산업심리학과 박사과정

- 주관심분야 : $3 \mathrm{D}$ 휴먼팩터, 시지각

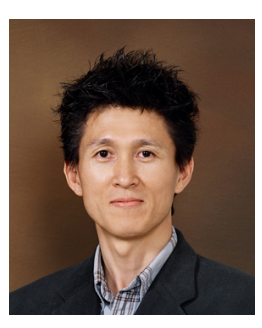

\section{이 형 철}

- 1987년 : 연세대학교 심리학과 학사

- 1989년 : 연세대학교 심리학과 석사

- 1996년: 미국 University of Wisconsin, Madison, 심리학과 박사

- 1999년 현재 : 광운대학교 산업심리학과 교수

- 2010년 2011년 : TTA, 3DTV PG, 품질안전규격 WG 의장

- 2010년 2011년 : 3D 시청 안전성 협의회 의장

- 주관심분야 : 3D 휴먼팩터, 시지각, Brain-Computer Interface

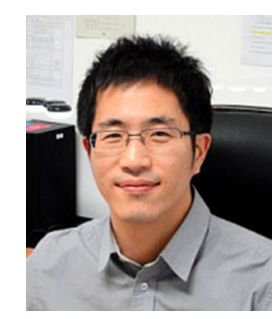

\section{김 신 우}

- 2003년 : 연세대학교 심리학과 학사

- 2007년 : New York University 심리학과 석사

- 2010년 : New York University 심리학과 박사

- 2010년 현재 : 광운대학교 산업심리학과 조교수

- 2010년 현재 : 감성과학회 편집위원

- 주관심분야 : 시선추적, 범주화, 인과관계, 개념학습, 추론, 사용성 